\title{
Framework for Management of Post-Conflict Waste in Libya
}

\author{
Ashraf Ali \\ Chukwunonye Ezeah
}

Faculty of Sciences and Engineering, University of Wolverhampton, City Campus-South, Wolverhampton, UK

doi: 10.19044/esj.2017.v13n5p32 URL:http://dx.doi.org/10.19044/esj.2017.v13n5p32

\begin{abstract}
An important aspect of the Libyan conflict since the 2011 Arab Spring is the generation and management of huge volumes of construction and demolition (C\&D) type waste, arising from conflict-related damage to the built environment. Estimates put the amount of Post-Conflict Waste (PCW) at about 82 million tonnes, much of which comprises potentially useful materials that could be reused or further processed and used in construction and other sectors of the economy. This paper presents and discusses the challenges that affect the use, reuse and recycling of such materials. To validate findings from literature, a pilot questionnaire survey of 70 professionals working in the waste management sector was carried out to identify the barriers constraining sustainable management of solid waste stream in three major Libyan cities. Data analysis was carried out using SPSS version 20.0. Based on the identified barriers, a framework for sustainable management of post-conflict waste arising in Libya has been designed in line with the medium-term infrastructure development objectives of the Libyan government. The paper recommends an urgent revision of applicable legislation and the formulation of new ones to address identified gaps in sustainable waste management. It is envisaged that results from this study will help underpin post-conflict sustainable development goals in Libya.
\end{abstract}

Keywords: Post-conflict waste, waste management, Libya

\section{Introduction}

Disaster and disruption could be of natural (e.g. floods, drought, volcanic eruptions, and earthquakes) or man-made causes (e.g. conflicts and terrorist attacks). In either case, the effect on the natural and built environment is often quite significant in terms of the destruction of 
infrastructure, apart from other physical and social impacts (Brown et al., 2011a). Conflicts and disasters usually result in the production of significant amounts of waste due to destruction or damage to properties and infrastructure. The volume of waste produced by wars and conflicts over a relatively short period of time can sometimes equal many times the amount of annual waste generation in peace time. The largest component of urban disaster waste would meet the peace-time classification of Construction and Demolition(C\&D) waste (Dubey et al., 2007). In recent experience, disasters in Beirut (Lebanon), Kobe (Japan), and Mostar (Bosnia) indicate that one of the most important challenges of disaster response is construction and demolition (C\&D) waste management (Lauritzen, 1998). Throughout conflict and into post-conflict periods, rehabilitation and reconstruction works generate significant C\&D waste from destroyed buildings and other infrastructure. For example, in the city of Mostar over 1000 buildings were destroyed, which was estimated to generate about 200,000 tons of C\&D waste (Lauritzen, 1995), whereas in Lebanon the rehabilitation and reconstruction of Beirut central district produced about 4 million tons of C\&D waste in 1994 (Lauritzen, 1998). In Kosovo about 10 million tons of waste was produced by 70,000 destroyed buildings. In the Gaza Strip in 2008 around 10,000 houses were completely destroyed (Salemdeeb and Bjerregaard, 2014). The accumulation of demolition waste in urban areas is usually a major logistic/operational challenge during recovery works, which hampers reconstruction by blocking access for collection services and attracting more secondary waste from the populace, which also constitutes health hazards (Baycan and Petersen, 2002). It is impossible to avoid waste during disaster, thus waste minimisation becomes the main management strategy (Karunasena and Amaratunga, 2016). In addition, because of destruction caused by prolonged conflicts, it is often difficult to implement long-term environmental policies; in such situations, short-term waste management strategies are required to achieve immediate objectives, for example the restoration of dumpsites following uncontrolled open dumping of waste in unauthorised locations (Lauritzen, 1998; Petersen, 2004). It is however necessary to indicate that PCW management strategies depend on specific contexts such as regional situations. In general, previous studies indicate that knowledge of disaster waste management is difficult to transfer from one context to another (Brown, 2012).

\section{Overview of solid waste management in Libya}

Libya is in North Africa and is the third-largest country in Africa by land mass, with a total land area of 1.757 million $\mathrm{km}^{2}$. The country is bounded by the Mediterranean Sea in the North, Egypt in the East, the Republic of Sudan in the South-East, Chad and Niger in the South, Algeria 
in the South-West and Tunisia in the North-West (Figure 1). Libya is divided into three states, Tripolitania, Cyrenaica and Fezzan, which enjoyed federal status from independence in 1951 until 1963, when the country became a unitary state. In 2011, after 42 years of military rule, the country was thrown into civil war following a violent regime change. Prior to onset of conflict, waste management in Libya was at best rudimentary. As a result of the destruction of buildings and other structures occasioned by the conflicts, significant volumes of C\&D waste accumulated in major cities and towns such as Sirte, Misrata and Hun. These volumes of C\&D waste continue to increase, particularly since the inception of "Operation Dignity" in 2014 in Benghazi which is in the eastern part of Libya. Figure (2) illustrates the types of buildings damaged, the extent of damage and some PCW in the foreground.



Figure (1) Libyan map and location. Source: National Geographic (2009)

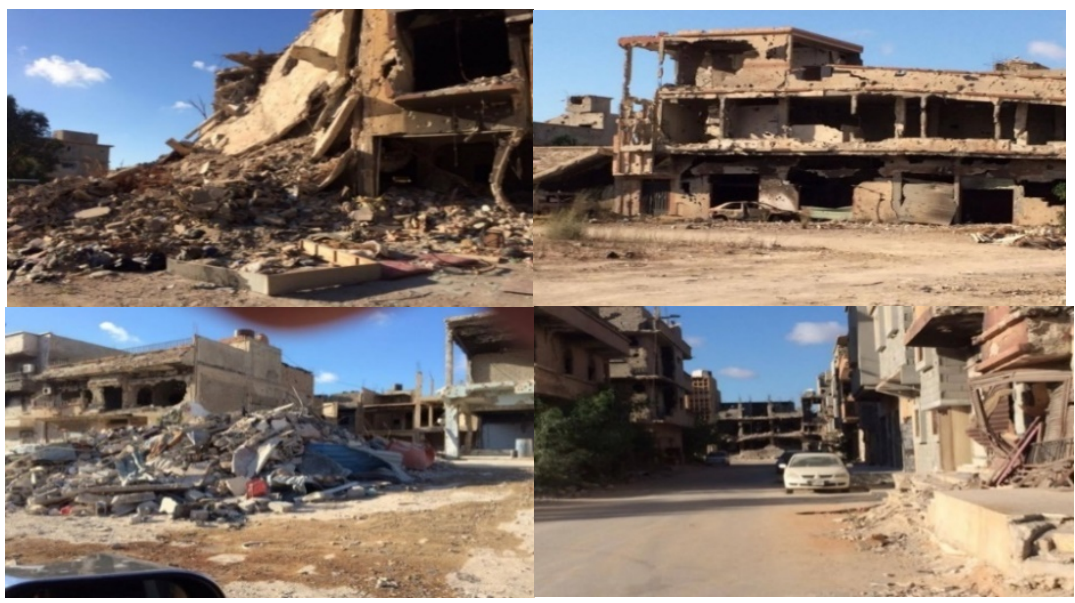

Figure (2) PCW from buildings damaged in Benghazi (Author's photos) 


\section{Solid waste generation in Libya}

A study by the Ministry of Housing and Public Utility in 2004 revealed that the per capita generation of solid waste in Tripoli city was $0.77 \mathrm{~kg} /$ day. This was corroborated in a recent study by Moftah et al. (2016), who found that the average household in the Tripoli area generates $0.7 \mathrm{~kg}$ of waste per day. The study indicates that the rate of waste generation sometimes varied remarkably between different zones of the same area (e.g. the waste generation rate was found to be 0.59 and $0.74 \mathrm{~kg} / \mathrm{capita} /$ day in areas 1 and 2, respectively, and $0.78 \mathrm{~kg} /$ capita/day in area 3). Another study by Hamad et al. (2014) reported that Libya produced 6,301 tons per day or an average rate of $1.12 \mathrm{~kg} / \mathrm{capita} /$ day of waste. In the absence of accurate data on municipal waste generation, the relevant authorities (the Ministry of Housing and Public Utilities (MHPU), Municipality of Tripoli (MT) and Tripoli Public Service Company (TPSC)) agreed to adopt the value of $1.0 \mathrm{~kg}$ per person per day of municipal waste (household, commercial and industrial waste combined) as a standard to calculate the quantities of solid waste generated within their jurisdictions and for contract procedures. Etriki (2013) demonstrated that the total quantity of MSW generation is expected to increase by an average of $2.5 \%$ from 6.64 million tons in 2010 to 11.68 million tonnes by 2020, and the quantity of waste generated per capita is expected to increase from $1.090 \mathrm{~kg} /$ person/day to $1.290 \mathrm{~kg} /$ person/day by 2030. Hamad et al. (2014) estimated that the overall generation of industrial solid waste, including non-hazardous wastes as well as C\&D waste, comprises 1,248,000 tons/year, with an accumulated quantity of 2,196,480 tonnes. According to Abukersh (2009), the annual tonnage of C\&D waste produced in Libya is estimated in the range of 400-450 kg per capita. Ali et al. (2016) estimated that total Libyan C\&D waste arising based on annual cement consumption was 3,641,150 tonnes in 2010.

\section{Solid waste characterization in Libya}

Waste characterization is a technique utilized to define the "character" or composition of materials contained in a waste stream. An itemized characterisation of solid waste is particularly essential for integrated solid waste management systems to be successful (Sakai et al., 1996). In Libya there has been no research focused on understanding the character and composition of C\&D and PCW waste streams. According to Brunner and Ernst (1986) and Martin et al. (1995), the most precise methods for characterising waste composition consist of collecting waste at source and categorizing the sample into kinds of materials. Saleh (2005) summarized solid waste components in Libya into three groups: (i) all domestic and similar waste from households; (ii) industrial wastes, including those generated by industrial and commercial activities, special inflammable 
substances, car bodies and C\&D waste; and (iii) septic wastes including waste from farms, hospitals, clinics, pharmacies, and laboratories. The nature of waste generated in Libya indicates some variation over the seasons. The General Environmental Agency (EGA, 2002) estimated annual volumes of waste production in Libya in 2002 to be 300,000 ton for organic waste and 230,000 ton for hazardous waste. On the other hand, Hamad et al. (2014) categorised solid waste into seven groups: biodegradable waste, recyclable materials, inert waste, composite waste, plastics waste, domestic hazardous and toxic waste.

In their waste characterization study conducted in Tripoli, Moftah et al. (2016) reported a per capita average production of MSW of $1415 \mathrm{~kg}$, representing a daily production rate of $0.64 \mathrm{~kg}$ per capita (total volume of $19.3 \mathrm{~m}^{3}$ with a density of $74.4 \mathrm{~kg} / \mathrm{m}^{3}$ ). Domestic solid waste generation comprises 36.3\% organic matter and 32.5\% recyclable materials such as glass, paper, plastic, metals. Table (1) illustrates the changing face of MSW composition in the country.

Table (1) The changing face of municipal solid waste composition rate in Libya

\begin{tabular}{|l|l|l|l|l|}
\hline \multirow{2}{*}{ Components } & \multicolumn{4}{|c|}{$\%$} \\
\cline { 2 - 5 } & $1971^{\star}$ & $2002^{\star}$ & $2008^{\star \star}$ & $2010^{\star \star \star}$ \\
\hline Organic material & 48.8 & 52.6 & 56.3 & 70.1 \\
\hline Plastics & 19.5 & 16.9 & 10.0 & 7.5 \\
\hline Paper \& Cardboard & 2.1 & 13.2 & 13.5 & 5.5 \\
\hline Metals & 3.8 & 7.8 & 3.7 & 4.3 \\
\hline Textiles & 3.1 & 4.2 & 10.8 & 1.3 \\
\hline Glass & 3.3 & 2.5 & 2.6 & 3.1 \\
\hline Timber & 1.9 & 1.3 & 0.8 & 2.5 \\
\hline Dust, stones, ashes, etc... & 16.7 & 1.4 & 2.0 & 2.5 \\
\hline
\end{tabular}

Source: (Etriki, 2013; Hamad, 2014) * EGA; **Municipality of Tripoli; *** EGA/UNDP

Preliminary estimates for Libyan cities revealed that 25\% of the waste generated in the country could be recycled (Alhamroush, 2005). Although the economic and environmental benefits of waste recycling are obvious, currently actual recovery or recycling rates are quite negligible, with only $1 \%$ for recycling and $2 \%$ for composting. Table (2) illustrates the recycling potentials for Libyan cities; in practice, not much is being done by the state in this regard, and nothing by the private sector except for informal recyclers (i.e. scrap merchants). Based on fieldwork conducted in 2010, Etriki (2013) made the following observations about the status of recycling activities in Tripoli:

- $\quad$ Material recycling is mostly carried out informally

- $\quad$ Recycling rate is extremely low $(<2 \%)$

- Informal sector recyclers 'scrap merchants' only target materials that have ready market value (e.g. copper wiring) and that can be used as raw material in new production by SMEs (e.g. high-grade hardwood fittings). 
- $\quad$ Recycling firms in Tripoli collect material for treatment from individual scavengers, with little interest in its provenance.

- $\quad$ Door to door collection of segregated waste is not currently practiced.

The rate of waste generation in Libya differs based on the location and income level of the city (Saleh, 2005). On average, Faras and Al Kario (2004) reported that each Libyan citizen generates between $0.35 \mathrm{~kg} /$ day to $2.00 \mathrm{~kg} /$ day, with an average of $0.78 \mathrm{~kg}$ per capita.

\section{Institutional Framework for Waste and Environment Management in Libya}

In the last four decades, solid waste management in Libya had fallen under different administrations. By the late 1970s all waste collection and disposal was carried out by private companies which handled the collection and final disposal of solid waste, until such companies were nationalised and came under the control of municipal authorities. Subsequently, responsibility for waste management was transferred to Environmental Protection Agency and the General People's Committee for Housing, Utilities and Environmental Protection Authority, which later merged with Operations and Maintenance Authority (formerly called the General Companies for Cleanliness) and was charged with the responsibilities of street cleaning, parks and land maintenance, beach cleaning, and the collection, transfer and disposal of collected waste. The Secretariat of the General Peoples Committees for Utilities of Housing and Environment is responsible for solid waste collection, transport, and disposal. Table (2) shows the historical outline of institutional frameworks for solid waste management in Tripoli between 1970-2006.

\begin{tabular}{c|c|c}
\hline \multicolumn{2}{c|}{ Table 2: Developments in municipal solid waste management in Tripoli, Libya (1970-2006) } \\
\hline Period & Management agency & $\begin{array}{c}\text { No of decree } \\
\text { (resolution) }\end{array}$ \\
\hline Before 1970 & Private Sector companies & - \\
\hline Until 1980 & Municipality of Tripoli & - \\
\hline $\mathbf{1 9 8 1 - 1 9 8 6}$ & Environmental Protection Agency & $45 / 1981$ \\
\hline $\mathbf{1 9 8 6 - 1 9 8 7}$ & Environmental Protection Agency + Operating and & $192 / 1986$ \\
\hline $\mathbf{1 9 8 7 - 1 9 9 9}$ & Maintenance System \\
\hline $\mathbf{1 9 9 9 - 2 0 0 3}$ & General Cleanliness Company & $394 / 1987$ \\
\hline $\mathbf{2 0 0 3 - 2 0 0 6}$ & Company of Public Authority & $11 / 1999$ \\
\hline $\mathbf{2 0 0 6}$ & Company of Occupancies and Public Services & $78 / 2003$ \\
\hline
\end{tabular}

Source: Eltriki (2013)

Most recently, Local Authorities have been responsible for waste collection and disposal in each municipality, being charged with setting up places for the disposal of construction waste and end of life vehicles, either severally or jointly. In addition, municipalities must report on the quantity of 
recycled solid waste, composition and other key indicators to the Environmental Protection Minister.

The Environment General Authority (EGA) has overall environmental regulation responsibility in Libya. It was established in 1982 to replace the Technical Centre for Environmental Protection. The General People's Committee for Health and Environment established the EGA by Resolution No. 263 of the year 2000 as an independent institution. Provisions of this legislation was subsequently harmonised with Resolution No. 15 of 2003. Regionally, the EGA has seven branches, each having responsibility for a separate zone in the country.

\section{Post-conflict and disasters waste management in Libya}

In general, Libya suffers from inefficient municipal solid waste management (MSWM) and a lack of sanitary landfills, and the efficiency of solid waste collection is very low (European Commission, 2009). Most urban solid waste is dumped and burned on empty plots within urban limits, with associated health problems. Most of the collected waste is deposited in dumps without consideration of the negative impacts of such dumping. Saleh (2005) reported that all types of waste are mixed together without any form of segregation, treatment, or recycling (e.g. materials like plastics, paper and glass are collectively landfilled rather than separated and recycled to decrease waste and increase economic efficiency). In recent times, despite Libya being particularly active in environmental protection legislation relative to African standards, no significant action has been taken to promote sustainable waste management, and no nationally coordinated strategies are in place either, particularly in terms of legislation for conflict and disaster waste management; there are no specific laws except Law No. 11 of 1971 regarding civil defense, which merely mentioned some procedures (e.g. detection of unexploded bombs and lifting operations, preparing teams and rubble removal, and organising equipment and tools and warnings for air raids). In addition, there is also Decision No. 184 of 2012, concerning citizens' compensation in cases of natural disasters and calamities. It follows therefore that now, Libya has no clear strategies to deal with conflicts and disasters waste issues, despite the huge volumes of PCW waste being generated because of the ongoing conflict in the country.

\section{Making a Case for Sustainable Post Conflict Waste Management}

Construction and Demolition waste generation is inevitable even in peace times. The problem is often magnified in conflict and post-conflict scenarios due to the destruction of infrastructure and reconstruction 
activities. During this time, PCW arising is often compounded with hazardous and clinical waste (mostly from humanitarian assistance sector) all of which impose extraordinary burdens on local facilities for processing waste, bearing in mind that institutional bodies are generally weakened by conflict (Mensah, 2006). Management of C\&D/PCW usually comprises normal processes of waste management, including collecting, transporting, processing and landfilling waste produced by several activities, except where waste is contaminated with hazardous materials. (Karunasena et al., 2013). C\&D waste is often collected and mixed with municipal wastes and disposed together, this practice often overburdens collection and recycling capacity (United Nations, 2003). Consequently, a more sustainable framework for management of PCW is urgently required in the country. A possible pathway for management of waste and other environmental aspects in conflict situations would include: access to site, search and rescue, site evaluation, demolition, rehabilitation, and reconstruction. Having said this, we note that there could be a slight difference between post-conflict and natural disaster waste processing, as outlined in Table (3).

\begin{tabular}{cc}
\hline \multicolumn{2}{c}{ Table (3) Difference between post-conflicts and disaster waste } \\
\hline Post-conflict building & Disasters waste \\
"Waste often contains reduced amounts of & "The nature and scale of waste following a disaster \\
timber, furnishings and personal possessions & varies considerably from one situation to another. In \\
since the buildings will often have been & post-tsunami situations, for instance, the majority of \\
burned. In post-conflict situations there is, & solid building waste could be washed out to sea by \\
however, a risk of unexploded ordnances & the receding waves. What may remain, however, is a \\
(UXO), mines and booby traps being present & large volume of mud into which other materials may \\
in the building waste. In such instances, & be mixed, which may prove difficult for sorting. In \\
access should be restricted until & contrast, post-earthquake debris will often have all \\
professionals have first cleared the area". & of the materials from the buildings still present at the \\
& footprint of the building”.
\end{tabular}

Source: Planning Centralised Building Waste Management Programmes in Response to Large Disasters

\section{Research methodology}

A multi methods approach was adopted in collecting primary data for this research, including a comprehensive literature survey of official reports by government agencies on rehabilitation and reconstruction efforts, text books, journal articles, conference proceedings and electronic databases. To validate findings from literature, a pilot questionnaire survey of 70 professionals working in the waste management sector was carried out to identify the barriers constraining sustainable management of solid waste stream in three major Libyan cities. Questionnaire administration was carried out via a self-administered approach using Google Forms. In total, 59 questionnaires were returned, equivalent to a $59 \%$ return rate. Data analysis was carried out using SPSS version 20.0. Based on the results of data analysis, a framework for management of post-conflict waste was developed. 


\section{Quantity of Post-conflict Waste C\&D in Libya}

Elzahari et al. (2013) in their study "Recycling Materials from Damaged Buildings" estimated that approximately 45,000 housing units required rehabilitation or rebuilding following the 2011 conflicts in Libya. This large-scale destruction of buildings and other structures, yielded more than 80 million tons of $C \& D$ waste, which is more than the volume generated by about15 European countries combined, and 22 times the amount of C\&D waste estimated in 2010 by Ali et al. (2016), and about three times the amount of C\&D waste generated in the immediate period preceding the conflicts (1992-2010).

\section{Barriers to PCW recycling}

Recycling is a fundamental strategy option for any sustainable PCW management. In the case of Libya, several barriers have been identified that inhibit PCW recycling, as summarized in Table (4).

\begin{tabular}{|c|c|c|}
\hline \multicolumn{3}{|c|}{ Table (4) Barriers to post-conflict waste recycling } \\
\hline Barriers & Title of study & Reference \\
\hline $\begin{array}{l}\text { The time to collect and process } \\
\text { the materials }\end{array}$ & Disaster waste management & $\begin{array}{c}\text { (Baycan and Petersen, 2002; } \\
\text { Brown, 2012) }\end{array}$ \\
\hline $\begin{array}{c}\text { Lack of specialists in PCW } \\
\text { management }\end{array}$ & Disaster waste management & $\begin{array}{c}\text { (Baycan and Petersen, 2002; } \\
\text { Brown, 2012) }\end{array}$ \\
\hline Lack of specialized equipment & Disaster waste management & $\begin{array}{c}\text { (Baycan and Petersen, 2002; } \\
\text { Brown, 2012) }\end{array}$ \\
\hline $\begin{array}{l}\text { the inability to physically } \\
\text { separate the materials }\end{array}$ & $\begin{array}{c}\text { Emergency construction } \\
\text { waste management/ } \\
\text { Emergency planning for } \\
\text { disaster waste: a proposal } \\
\text { based on the experience of } \\
\text { the Marmara Earthquake in } \\
\text { Turkey }\end{array}$ & $\begin{array}{c}\text { (Lauritzen, 1998; Baycan, 2004; } \\
\text { Brown, 2012) }\end{array}$ \\
\hline $\begin{array}{l}\text { The lack of desire to offset raw } \\
\text { material use in rebuild }\end{array}$ & $\begin{array}{l}\text { Emergency construction } \\
\text { waste management }\end{array}$ & (Lauritzen, 1998) \\
\hline Unavailability of disposal sites & $\begin{array}{l}\text { Emergency construction } \\
\text { waste management }\end{array}$ & (Lauritzen, 1998) \\
\hline $\begin{array}{l}\text { Unavailability of markets to } \\
\text { absorb large quantities of } \\
\text { material }\end{array}$ & $\begin{array}{l}\text { Disaster debris management/ } \\
\text { emergency construction } \\
\text { waste management }\end{array}$ & $\begin{array}{c}\text { (Solis et al., 1995; Lauritzen, } \\
\text { 1998; Brown, 2012;Salemdeeb \& } \\
\text { Bjerregaard, 2014). }\end{array}$ \\
\hline Contractual arrangements & $\begin{array}{l}\text { Disaster waste management: } \\
\text { A systems approach }\end{array}$ & (Brown, 2012) \\
\hline $\begin{array}{c}\text { Availability and feasibility of } \\
\text { alternative waste management } \\
\text { options }\end{array}$ & $\begin{array}{l}\text { Disaster waste management: } \\
\text { A systems approach }\end{array}$ & (Solis et al., 1995; Brown, 2012) \\
\hline Hazards in the waste matrix & $\begin{array}{l}\text { Disaster waste management: } \\
\text { A systems approach }\end{array}$ & (Brown, 2012) \\
\hline Displaced population & $\begin{array}{c}\text { Disaster waste management: } \\
\text { A systems approach }\end{array}$ & (Brown, 2012) \\
\hline
\end{tabular}




\section{Benefits of PCW recycling}

Case studies of major conflicts and disasters such as the Northridge Earthquake in the US in 1994 (Gulledge, 1995; USEPA, 2008), Thailand and Sri Lanka (Basnayake et al., 2005; UNDP, 2006), Kosovo (DANIDA, 2004) and Beirut (Jones, 1996), have reported various environmental, economic and social benefits of recycling PCW. Such benefits include reduction in the need for spaces for landfills/waste dump sites, resource conservation (particularly virgin materials), reductions in emissions and other impacts of transportation of both raw materials and waste as well as job creation. In the case of Libya, taking advantage of above listed benefits of recycling requires overcoming various barriers militating against PCW recycling (Solis et al., 1995; Lauritzen, 1998; Baycan and Petersen, 2002; Brown, 2012).

\section{Strategies for managing post-conflict $\mathrm{C} \& \mathrm{D} / \mathrm{PCW}$ waste in Libya}

In the context of Libya, implementing an effective PCW management strategy will constitute a crucial step to the overall national sustainable waste management plan. The PCW management strategy consists of three phases, as shown in Figure (3).

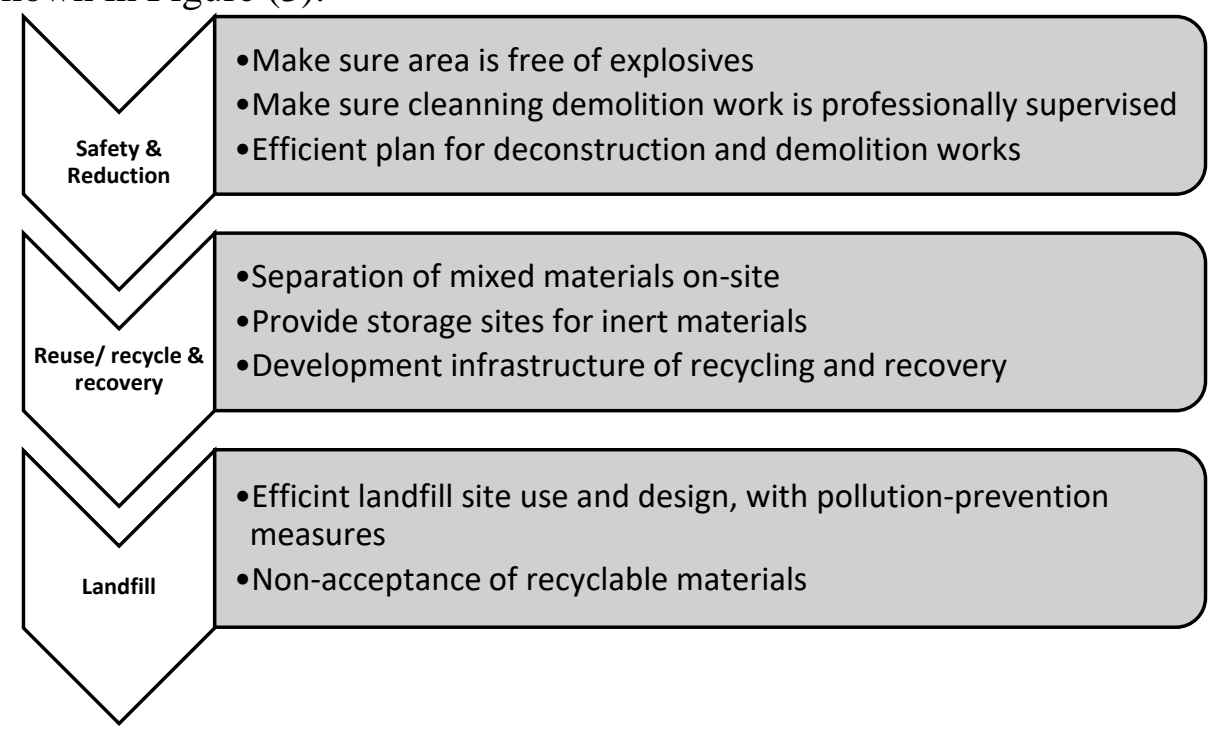

Figure (3) Conflict waste hierarchy

\section{Safety and reduction}

To assess the extent of following cessation of conflicts, access must be opened, rubble removed and unstable structures cleared to provide immediate safety and prepare for clean-up and reconstruction. The International Committee of the Red Cross noted that the international armed conflict in Libya in 2011 has resulted in widespread pollution throughout the country, with a large amount of abandoned munitions and unexploded 
ordnance, therefore professional bomb disposal units and technologies are required for the removal of post-conflict waste prior to conventional construction industry activities. Post-conflict waste materials can then be safely managed, with minimum amounts going to the landfill, based on the algorithm shown in Figure (4).

\section{Reuse and recycling}

There are significant potentials for recycling post-conflict wastes materials such as concrete, aggregates, soil for landfill cover and organic material for compost. The plausibility of recycling is subject to the expense of waste transfer (counting transportation), and the estimation of the value of the recycled substances related to the ease of use of the product and the expense of crude substances. Incentives are often provided to guarantee the economic value of recycling. Notwithstanding, environmental benefits are the main rationale for recycling in the construction industry

\section{Landfill}

Almost always, after major conflicts, volume of waste arising always surpasses available waste disposal capacity (Petersen, 2006). For instance, after Hurricane Katrina, open resistance to the extended waste approval standard at C\&D landfills prompted a claim being recorded and the possible closure of one landfill site, thus waste administrators were compelled to discover an alternate dumping site (Luther, 2008). To overcome this challenge, landfill should therefore be the last option for PCW management, strictly for elements which ordinarily are unsuitable for recycling or other forms of resource recovery.

To implement all these strategies, capacity and development building are urgently required in Libya. To build capacity some aspects should be considered such as a nation's human, technological, scientific and resources capabilities, which are linked to strategy selections and ways of application among advancement alternatives relative to the environmental potential and limits observed.

\section{Challenges and opportunities}

There are many challenges to managing post-conflict waste in Libya, for instance, distance between conflict locations, which sometimes could be considerable. Furthermore, conflict is still on-going in some areas. Having said this, there are a number of opportunities and success factors, such as potential economic benefits that could accrue from resource recovery as well as the possibility of assisting companies engaged in post-conflict reconstruction works to reuse recovered materials in post conflict 
reconstruction works in Libya. To adequately harness these benefits, this study proposes a framework for achieving the desired goals.

\section{Discussion}

Literature identified an incipient list of 11 barriers to recycling and reuse of C\&D waste in post-conflict situations. Results from our survey agree with the barriers identified from literature. This is in addition to nine more barriers to recycling and ruse of post-conflict/C\&D waste arising as listed below:

1. Many participants in this survey raised the issue of absence of reliable data.

2. Most participants felt that the government does not give serious attention to this issue.

3. Determining responsibility for waste management in Libya is the most immediate obstacle to sustainable PCW waste management.

4. There is a manifest lack of institutional responsibility to manage this type of waste.

5. There are no laws specific to C\&D and PCW management.

6. Dearth of specialized manpower with requisite experience in the management of PCW waste.

7. The public lack awareness of the importance of recycling and they fear that recycled construction materials are unsafe.

8. There is no support from the government to encourage private sector involvement.

9. There is inadequate financial support. 


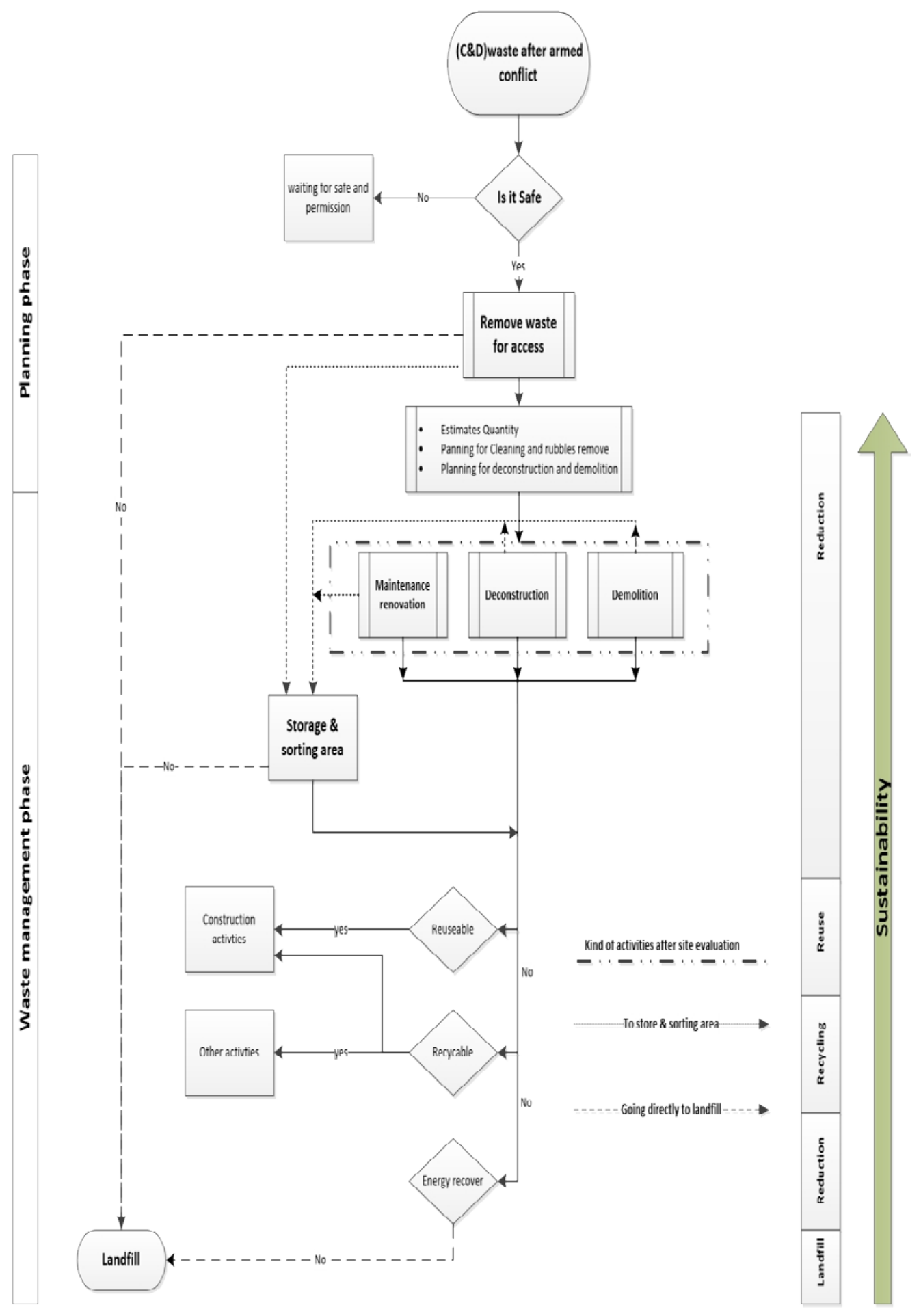

Figure (4): Algorithm for sustainable PCW management in Libya. 
A number of areas of commonality exist between the of barriers identified by literature and findings from analysis of research questionnaires in this study. The barriers could be categorized under five main dimensions:

- $\quad$ Dearth of specialized manpower: shortage of knowledge across waste management and requirement for training.

- Equipment and facilities: the lack of equipment and facilities fundamentally prevents access and processing.

- $\quad$ Policy and governance: legislative and regulatory obstacles to PCW management exist.

- $\quad$ Cultural perceptions: most participants do not consider post-conflict waste to be a potential profitable resource.

- $\quad$ Dearth of empirical data: severe absence of reliable data on PCW and other waste genre.

\section{Framework for management of post-conflict waste in Libya}

Flows of post-conflict waste are a long-term problem necessitating long-term solutions that are embedded into post-conflict reconstruction activities. Therefore, to overcome and minimize post-conflict waste, this framework is organized into four conceptual phases based on capacity- and development-building and waste hierarchy. Figure (5) illustrates the proposed framework. The second phase is waste estimation and establishment of transportation and right of way protocols. In the third phase, transformation, focus is on reducing negative environmental impacts on quality and ensuring the compliance of the materials with national standards for construction activities, which continues in the subsequent phases. The fourth phase entails several approaches for resources creation, while the final phase is waste disposal. In addition, legislative and regulatory inputs are required to foster these phases. It should be noted that emphasis should be placed on waste minimization as the main prong of sustainable management of PCW in the country (Alameda County Disaster Waste Management Plan, 1998; Baycan and Peterson, 2002). 


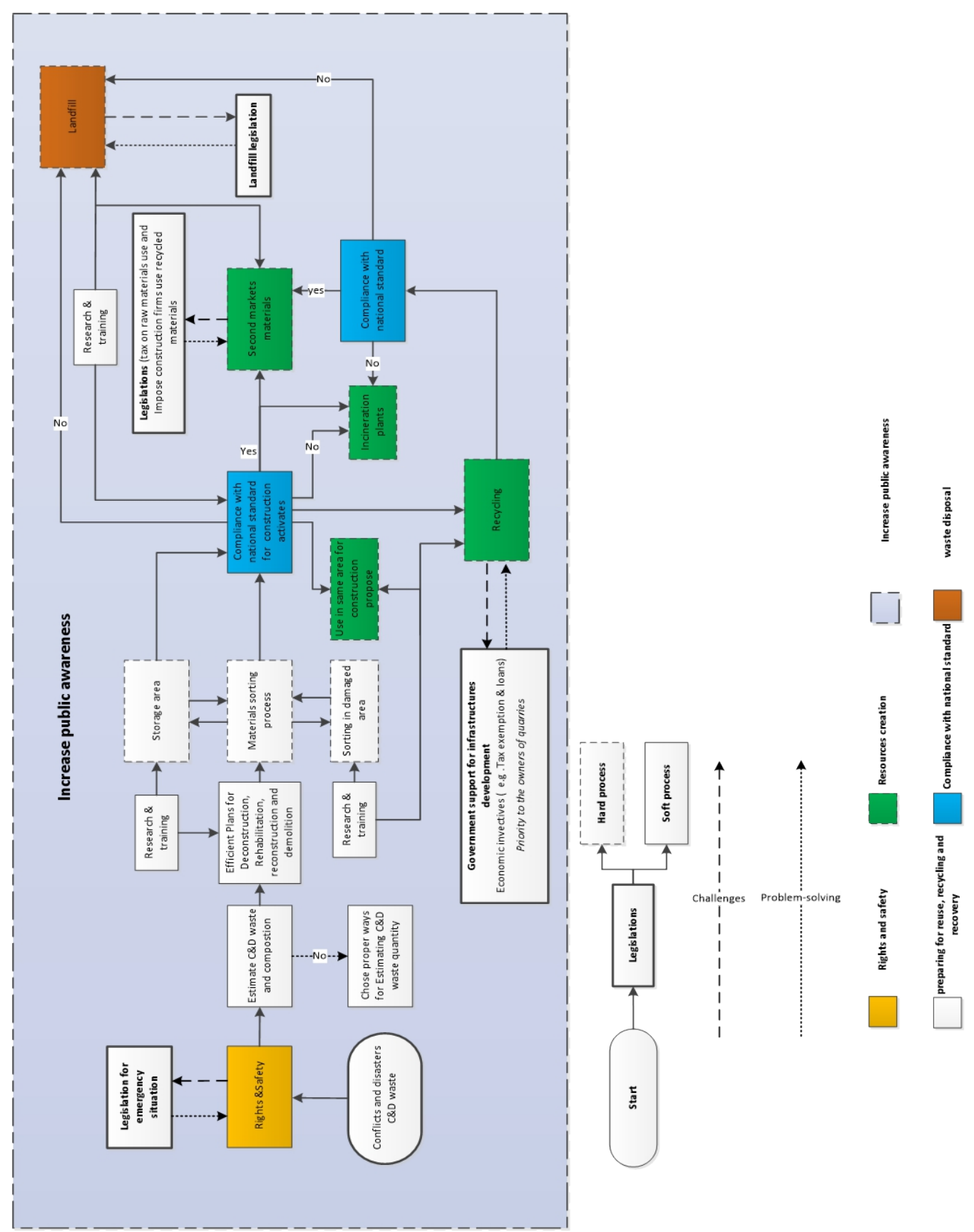

Figure (5) Framework for management of post-conflict waste in Libya

\section{Conclusion}

This study has proposed a framework for management of postconflict/C\&D waste in Libya. Generally, the paper argues that there are considerable hurdles to recycling and the reuse of post-conflict waste in 
Libya, which previous studies revealed to be universal. In other to overcome these barriers, the Libyan government must take urgent actions to promote waste management infrastructure development in addition to enacting legislation focused primarily on sustainable PCW/C\&D waste management. Legal provisions should promote the rights of workers who are engaged in the waste sector. Effort must also be made to encourage firms engaged in reconstruction works to use post-conflict waste materials for reconstruction works. The limitation of this study is that it focused mainly on post-conflict waste managment. It is suggested that a similar study should be undertaken focusing on other waste types so as to further underpin future waste management objectives in Libya.

\section{References:}

1. Abukersh, A. A. (2009) High quality recycled aggregate concrete. Doctoral Thesis, Edinburgh Napier University, UK

2. Alameda County Waste Management Authority (1998) Alameda County Disaster Waste Management.

3. Alhamroush A, Altabet A.(2005) Hospital waste in Misurata :problems, effects and methods of disposal. Master.Thesis. Libya: Medical Technical College Alfath University, Libya

4. Ali,ashraf., Ezeah,C., and Khatib, J(2016) estimating C\&D waste arising in Libya. The Thirty- First International Conference on Solid Waste Technology and Management.Widener University Philadelphia, PA U.S.A April 3-6, 2016.

5. Basnayake, B.F.A., Chiemchaisri, C., Mowjood, M.I.M. (2005) Solid wastes arise from the Asian tsunami disaster and their rehabilitation activities: case study of affected coastal belts in Sri Lanka and Thailand. In: Tenth International Waste

6. Baycan, F., \& Petersen, M. (2002) Disaster waste management C\&D waste. Proceedings of the ISWA 2002 annual congress, Istanbul

7. Brown, C. O.( 2012) Disaster Waste Management: a systems approach. Ph.D. Thesis, University of Canterbury

8. Brunner, P. H and Ernst, W.R .(1986) Alternative Methods for the Analysis of Municipal Solid Waste. Waste Management \& Research, 4, pp. 147-160.

9. DANIDA. (2004) Building Waste Management, Kosovo. DANIDA.

10. Dubey, B., Solo-Gabriele, H. M. \& Townsend, T. G. (2007) Quantities of Arsenic-Treated Wood in Demolition Debris Generated by Hurricane Katrina. Environmental Science \& Technology, 41(5), pp. 1533-1536. 
11. EGA 2002, The First National Report on the state of the Environment, Environmental General Authority, Tripoli, Libya

12. Elzahari, S. A., Ben Zara E., and Ghrooda, H. (2013) Recycle Material of the Damaged Buildings. 12th conference of the engineering construction,16th-18th December 2013 University of Tripoli, Libya 2013.

13. Etriki., J. (2013) Municipal solid waste management and institutions in Tripoli, Libya: applying the Environmentally Sound Technologies (ESTs) concept Unpublished Degree of Doctor of Philosophy., the University of Hull.

14. European Commission (2009) development solutions, MEC international limited and the University of Manchester Trade Sustainability Impact Assessment (SIA) of the EU- Libya Free Trade Agreement , Final report

15. Faras, B. Al Krio, Z. (2004) Solid waste Management in Libya. Environmental management conference of Arab region Sharm El Sheikh, Egypt 21- 25 November

16. Gulledge, J.H. (1995) Calabasa landfill earthquake debris recovery programme. In: Earthquake Waste Symposium, 12-13 June 1995, Osaka

17. Hamad, T.A., Agll, A.A., Hamad, Y.M. and Sheffield, J.W. (2014) Solid waste as renewable source of energy: current and future possibility in Libya. Case Studies in Thermal Engineering [online], 4 pp. 144-152 Available at:<http://www.sciencedirect.com/science/article/pii/S2214157X1400 $032 \mathrm{X}>$.

18. Jones, D. (1996) Beirut, Capital of Lebanon: Waste Management after the War. Warmer Bulletin.

19. Karunasena , G. and Amaratunga ,D. (2016) Capacity building for post disaster construction and demolition waste management.Disaster Prevention and Management, 25 (2), pp. 137 - 153

20. Karunasena, G., Amaratunga, D. and Haigh, R. (2013) Framework for capacity building for post disaster construction \& demolition waste management at national level. In: 2013 International Conference on Building Resilience, 17th-19th September 2013, Heritance Ahungalla, Sri Lanka

21. Lauritzen, E.K. (1998) Emergency construction waste management. Safety Science [online], 30(1-2), pp. 45-53 Available at:<http://www.sciencedirect.com.ezproxy.wlv.ac.uk/science/article/p ii/S0925753598000320>.

22. Lauritzen, E.K., 1995. Solving disaster waste problems. In: Earthquake Waste Symposium, 12-13 June 1995, Osaka. 
23. Luther, L.(2008.) Disaster Debris Removal after Hurricane Katrina: Status and Associated Issues, Order Code RL33477, Congressional Research Service.

24. Martin, J. H., Collins, J. H. \& Diener, R. G. (1995) A Sampling Protocol for Composting, Recycling and Re-use of Municipal Solid Waste. J. Air \& Waste Manage. Assoc, 4 5,pp. 864-870.

25. Mensah, A. (2006). People and their waste in an emergency context: the case of Monrovia, Liberia. Habitat International, 30, 754-768

26. Moftah, W.A.S., Marković, D., Moftah, O.A.S. and Nesseef, L. (2016) Characterization of Household Solid Waste and Management in Tripoli City—Libya. Open Journal of Ecology, 6, pp. 435-442.

27. Petersen, M. (2004) Restoring waste management following disasters. International Conference and Student Competition on Postdisaster reconstruction "Planning for reconstruction" Coventry, UK, April 22-23, 2004.

28. Sakai, S., Sawell, S. E., Chandler, A. J., Eighmy, T. T., Kosson, D. S., Vehlow, J., van der Sloot, H. A., Hartlén, J and Hjelmar, O. (1996) World Trends in Municipal Solid Waste Management. Waste Management , 16(5/6), pp.341-350.

29. Saleh, A. A. (2005) The suitability of the Libyan soils for use as engineered landfill liners Unpublished A Doctoral Thesis, Loughborough University Institutional Repository

30. Salemdeeb, R. and BjerregaardR. M. (2014) Gaza: Toil and Rubble, Chartered Institution of Waste Management Journal. Report number 12

31. Solis, G.Y., Hightower, H.C., Sussex, J., and Kawaguchi, J. (1995) Disaster Debris Management, Final Report ed. The Disaster Preparedness Resources Centre, The University of British Columbia for Emergency Preparedness Canada, British Columbia.

32. The General Environmental Agency, GEA, Libya (2003). Unpublished report. (In Arabic).

33. UNDP. (2006) Tsunami Recovery Waste Management Programme. Multi Donor Fund for Aceh and Nias. UNDP

34. United Nations (2003). Afghanistan. Post-conflict environmental assessment. United Nations, Nairobi: United Nations Environment Programme

35. USEPA (2008) Planning for natural disaster debris. In: Office of Solid Waste and Emergency Response and Office of Solid Waste (Eds.). 